\title{
ASSESSMENT OF SOURCE PROFILES FOR SUSPENDED PARTICULATE POLLUTANTS IN IBADAN, NIGERIA USING POSITIVE MATRIX FACTORIZATION
}

\author{
Akinlade G. O.*ª Owoade, O. K. ${ }^{a}$, Olise, F. S., Almeida, S. M. ${ }^{b}$, Faria, T.', \\ Almeida-Silva, M. ${ }^{\mathrm{b}}$, Olaniyi, H. B. ${ }^{\mathrm{a}}$ and Hopke, P. K. ${ }^{\mathrm{c}}$ \\ ${ }^{a}$ Department of Physics, Obafemi Awolowo University, Ile-Ife, 220005, Nigeria. \\ ${ }^{b}$ C2TN, Instituto Superior Tcnico, Universidade de Lisboa, EN10, km 139, 7,2695-066 Bobadela LRS, Portugal. \\ 'Department of Chemical and Bimolecular Engineering and Centre for Air Resources Engineering and Science, \\ Clarkson University, Potsdam, NY, USA. \\ *Corresponding author: gakinlade@oauife.edu.ng \\ Other authors' e-mail: oowoade@oauife.edu.ng; felix_rsh@yahoo.com; smarta@itn.tecnico.ulisboa.pt; \\ tiagofaria@itn.tecnico.ulisboa.pt; marina@itn.tecnico.ulisboa.pt; hbolaniyi@yahoo.co.uk; hopkepk@clarkson.edu
} (Received: $13^{\text {th }}$ November, 2018; Accepted: $29^{\text {th }}$ January, 2019)

\begin{abstract}
known as EPA PMF receptor model and reconstructed mass model were applied to air pollution data collected over Ibadan south west Nigeria. The essence was to determine the source profiles responsible for the high pollution level of Ibadan and to compare the sources resolved by these two methods. Particulate matter load was sampled over Ibadan, southwest Nigeria with the aid of low volume Gent air sampler, equipped with the Norwegian Institute for Air Research (NILU) Stacked Filter Unit (SFU). Two separate 47-mm nuclepore filters were mounted on the SFU to collect both fine and coarse particulates separately. Trace elements were determined using instrumental neutron activation analysis (INAA) and energy dispersive $\mathrm{x}$-ray fluorescence (EDXRF) spectrometry. Five factors were resolved each for both fine and coarse fractions using EPA PMF. For the fine fraction, soil dust, vehicular emission, oil combustion, open burning and copper-rich source were the major sources of fine particulates over Ibadan city contributing 42,16,10,22 and 10\% respectively to the total aerosol loading over Ibadan. Vehicular emission, continental soil, sea salt, locally generated dust and copper-rich source were the sources identified for the coarse particulates. These contributed 7, 49, 13, 23 and $8 \%$ respectively. It was observed that emission from open burning was very high $(22 \%)$, being the second largest contributor to the fine particulates. Reconstructed mass model showed good agreement with PMF in implicating soil dust as the major contributor of airborne pollutants over Ibadan. There was good correlation between the reconstructed mass and the measured mass with $r^{2}$ values of 0.87 and 0.98 for fine and coarse particulates respectively. The result of this work showed that re-suspended soil particulates were the major constituents of airborne particulate matter over Ibadan, with over $70 \%$ contribution to the coarse mass and over $40 \%$ contribution to the fine mass.
\end{abstract}

Keywords: Particulate Matter, Reconstructed mass, Refuse burning, PMF, Receptor model, Composite Variables

\section{INTRODUCTION}

Airborne particulate pollutants especially the fine fraction, have been linked to various health issues ranging from hospital admission to cardiovascular diseases (Pope et al., 2002; Almeida et al. 2014a). To reduce the health risk associated with suspended particulates, the knowledge of the sources and sinks of these pollutants is highly needed; source profiles must be studied and quantified. This will enable the relevant body establish necessary policy with a view to nip the problem in the bud.

One of the ways by which this can be achieved is by carrying out emission inventories of all polluting sources, which is usually very expensive to carry out. Alternatively, factor analysis models are applied to measured pollutants' concentrations at receptor sites in order to provide information on the possible sources. Such models include principal component analysis (PCA) and multilinear regression analysis (MLRA). However, the presence of negative loadings for certain species is a major limitation to the use of some of these models (Lee et al., 1999). A better approach is the use of PMF receptor model with a built-in non negativity of factors to identify various sources of particulate pollutant. The output of 
the PMF receptor model gives the source profiles and factor contribution to species. The model achieved this by carrying out the multilinear regression of the input matrix. PMF does not rely only on information from the correlation matrix but also carries out a point by point least squares minimization scheme which produces a better result. Identification of each factor is then based on the knowledge of different sources emitting those pollutants.

Identification of source profiles can also be done using calculations of pseudo elemental and composite variables which add up to give the reconstructed mass (RCM). Calculation of composite variables are necessary because the detected elements would not add up to the measured PM mass since the detected elements are thought of as not existing in isolation but in compound form. But when the contributions of these compounds are calculated, we have the reconstructed mass (RCM). It has been established by many researchers that the RCM correlates well with the $\mathrm{PM}_{2.5}$ mass (Cohen, 1999). This work however goes further to find the correlation between the RCM and the coarse fraction. Rees et al. (2004) investigated the difference between the RCM and the PM mass measurement and established that the difference was due to the presence of moisture and volatilization.

Ibadan as one of the major cities located in southwestern part of Nigeria has been reported to have elevated level of suspended particulates (Akinlade, et al, 2015). The authors established that these particulates were both of natural and anthropogenic sources. Probable natural sources include road dust re-suspension as many roads remained unpaved and the volume of cars plying the roads are very high due to poor public transport system in the country. Earlier work done on air pollution study of Ibadan is very few and that is why this work is very important in providing baseline data for future work in the city. The essence of this work is therefore to identify and quantify various sources of particulate pollutants in Ibadan, southwestern Nigeria using PMF and reconstructed mass model for both the fine and coarse fractions of PM.

\section{MATERIALS AND METHODS}

\section{Site Description}

The study area has a geographical location of longitude $3.5^{\circ} \mathrm{E}$ and latitude $7.2^{\circ} \mathrm{N}$ with an average altitude of $200 \mathrm{~m}$ above mean sea level. Basically, Ibadan experiences two major climatic seasons, dry and wet, determined by the meridional movement of the inter-tropical discontinuity (ITD) line which is the separation between the North-East Trade Winds and the South-West Trade Winds. Whenever the city is north of ITD line, the prevailing wind is the dry and dust laden north-easterlies, locally referred to as Harmattan which occurs within the dry season between November and February. However, when the city is south of the ITD line, the prevailing wind is the moist, warm south westerlies experienced in the raining season (between March and October).

Figure 1 shows the six locations within Ibadan metropolis chosen as measurement sites; Site 1 (Latitude $7.42^{\circ} \mathrm{N}$, Longitude $3.90^{\circ} \mathrm{E}$ ) is within Bodija near the State Housing Corporation. The sparsely populated community comprised mainly the elites. However, the volume of cars plying its paved roads is moderate. Site 2 (Lat. $7.44^{\circ} \mathrm{N}$, Long. $3.90^{\circ} \mathrm{E}$ ), is located within the University of Ibadan Campus. The location is such that it is far away from any significant pollution source. Thus this site was selected as a control site. Site 3 (Lat. $7.39^{\circ} \mathrm{N}$, Long. $3.88^{\circ} \mathrm{E}$ ), Dugbe, is adjacent to the magnificent building popularly called Cocoa house. Dugbe is more of a commercial center. The Ogunpa market is a few meters away to the east and several big shops are located in the area. Because of this, the volume of vehicles plying its paved roads is considerably high. Site 4 (Lat. $7.36^{\circ} \mathrm{N}$, Long. $3.85^{\circ} \mathrm{E}$ ) is located at Oluyole industrial estate. This area hosts major factories located in Ibadan with few residential houses scattered round it. Heavy trucks were very frequent in the region during the period of this study and the roads were unpaved. Site 5 (Lat. $7.40^{\circ} \mathrm{N}$, Long. $3.95^{\circ} \mathrm{E}$ ) is located at the Iwo Road along the new Ife road. Very close to the site is a motor park with few people selling some commodities and food items. This road has been described as the most congested in Ibadan (Eluwa, 2012), being a major highway. The last site, Aperin 
(Lat. $7.37^{\circ} \mathrm{N}$, Long. $3.92^{\circ} \mathrm{E}$ ), is located far away from traffic within the Olubadan High School premises. The community is in the core parts of Ibadan where many ancient buildings were found,
Aperin was rated as one of the high population density areas of Ibadan metropolis (Kayode, et al 2011). The description of the sites is presented in Table 1.

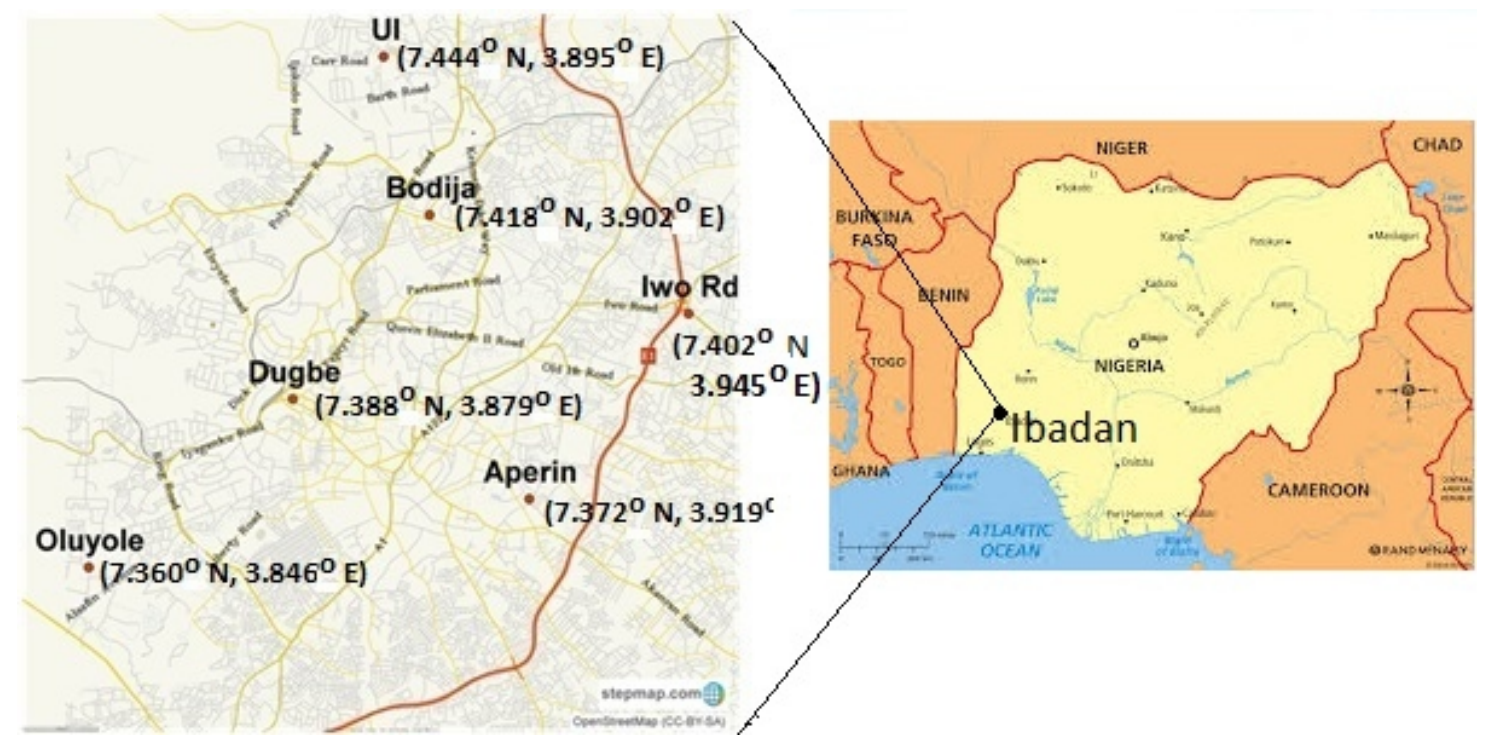

Figure 1: Map of Ibadan showing the six sampling locations

Table 1: Description of sampling sites

\begin{tabular}{|l|l|l|}
\hline Site & Coordinates & Class description \\
\hline Bodija & $7.42^{\circ} \mathrm{N}, 3.90^{\circ} \mathrm{E}$ & Low density residential area \\
\hline UI Campus & $7.44^{\circ} \mathrm{N}, 3.90^{\circ} \mathrm{E}$ & Control \\
\hline Dugbe & $7.39^{\circ} \mathrm{N}, 3.88^{\circ} \mathrm{E}$ & Commercial area \\
\hline Oluyole & $7.36^{\circ} \mathrm{N}, 3.85^{\circ} \mathrm{E}$ & Industrial/residential area \\
\hline Iwo Rd. & $7.40^{\circ} \mathrm{N}, 3.95^{\circ} \mathrm{E}$ & High traffic density area \\
\hline Aperin & $7.37^{\circ} \mathrm{N}, 3.92^{\circ} \mathrm{E}$ & High density residential area \\
\hline
\end{tabular}

\section{Sampling}

Air particulate sampling was carried out with the aid of low volume Gent air sampler (Hopke et al., 1997), equipped with the Norwegian Institute for Air Research (NILU) Stacked Filter Unit (SFU). Details of the sampling instrumentation and quality assurance procedure have been reported (Akinlade et al., 2015). The flow rates of the samplers were between 15 and $16 \mathrm{~L} / \mathrm{min}$ and the sampling period was at least eight hours in each location.

The samplings were done once every month at each location from July 2013 to February 2014, and also between March and June, 2015 covering all the months of the year. From the twelve months sampling, a total of 142 samples were obtained for both the coarse and fine particulate matter because due to logistic problem, sampling was done for only one hour in one of the locations in July, 2013 and because the sampling period did not conform with acceptable standard, the two samples were not included in the analysis.

\section{Chemical Analysis}

To allow for detection of more elements with good accuracies, elemental characterization was carried out using two analytical techniques; $\mathrm{x}$-ray fluorescence (XRF) spectrometry and instrumental neutron activation analysis (INAA). Black carbon analysis was carried out using a dualwavelength optical transmissometer data acquisition system from Magee Scientific. Both XRF and black carbon facilities were accessed at the Centre for Air Resources Engineering and Science, Clarkson University, Potsdam, NY, USA. 
Details of the two facilities have also been reported (Akinlade et al, 2015). The calibration (XRF) was done using reference material (SRM 2783); the results were compared with the certified values of elemental concentrations of the reference material.

For elemental characterization using INAA with the $\mathrm{k}_{0}$ methodology, weighed filter halves were rolled up and put in aluminum foil before irradiation. Samples wrapped with aluminum foil were arranged in irradiation containers with $\mathrm{Au}$ monitors (Al - $0.1 \%$ Au alloy, thickness: $125 \mu \mathrm{m}$; diameter: $5 \mathrm{~mm}$ ) placed at bottom and top of the containers to serve as comparators for monitoring the neutron flux. Standard reference material, NIST SRM-1633a coal fly ash (CFA) was also prepared as one of the samples to check and ascertain the quality of the results produced (Almeida et al., 2014b). The irradiation container was then put in a polythene bag for irradiation. Irradiations were done in a pool-type reactor at the Portuguese Research Reactor (nominal power 1 MW) located at Campus Tecnológico e Nuclear, Instituto Superior Técnico, Universidade de Lisboa. The samples and reference material together with the Au monitors were irradiated for 5 hours on Cell 55 with thermal neutron flux of about $1.2 \times 10^{13} \mathrm{~cm}^{-2} \mathrm{~s}^{-1}$. At the end of each irradiation, the capsule was returned from the reactor and allowed to decay until the activity level (count rate) was within the acceptable limit for handling (usually 2 to 3 days after irradiation). The samples together with the comparators and the reference material were then unpacked and put in separate containers for counting using a high purity calibrated hyper pure Ge (HPGe) detector. Countings were done for 7-12 hours, 2-3 days after the irradiation for the measurement of medium lived radionuclides and after 4 weeks for the long lived radionuclides' assessment. The detector used was liquid- $\mathrm{N}_{2}$-cooled, with full width at half maximum (FWHM) approximately $1.85 \mathrm{keV}$ at $1.33 \mathrm{MeV}$ (gamma ray line of ${ }^{60} \mathrm{Co}$ ).
The detector's relative efficiency was $30 \%$. The elemental concentrations were determined through the $\mathrm{k}_{0}$-IAEA software version 5.22. Choice of elements from the technique was based on the results of the analysis of the standard reference material and because the results of the analysis of standard reference material were mostly poor for most of the elements, only $\mathrm{Co}, \mathrm{Sc}$ and $\mathrm{Sb}$ analysed using INAA were used, the rest of the elements were determined using EDXRF technique.

Positive Matrix Factorization (PMF) Model

The PMF was used to resolve different factors contributing to pollutant concentrations measured at different receptor sites. Optimized concentration values from the XRF and INAA analyses were fed into the model as well as their respective uncertainty values. Measured concentrations for the PM were also included in the PMF input. In this work, missing concentration values were replaced with the median of the concentration values while the corresponding uncertainty was the median value multiplied by 4 (Paatero and Tapper, 1994). While this allowed the model to run without a missing value, the high uncertainty value attached to the median concentration values made the model pay little or no attention to the concentration value.

\section{Conditional Probability Function (CPF)}

CPF (Ashbaugh, et al., 1985) was used to analyze point source impacts from different wind directions using the source contribution estimates from PMF analysis. Wind speed and direction data was obtained from the nearest meteorological station located at the Ibadan international airport. The CPF estimates the probability that a given source contribution from a given wind direction will exceed a predetermined threshold criterion. The same daily contribution was assigned to each hour of a given day to match the hourly wind data. The CPF is defined as 


$$
C P F_{\Delta \theta}=\frac{m_{\Delta \theta}}{n_{\Delta \theta}}
$$

where $m_{\Delta \theta}$ is the number of occurrence from wind sector $\Delta \theta$ that exceeded the threshold criterion, and $n_{\Delta \theta}$ is the total number of data from the same wind sector. In this work, 32 sectors were used $(\Delta \theta$ $=11.25)$. Calm wind $\left(<1 \mathrm{~ms}^{-1}\right)$ periods were excluded from the analysis due to the isotropic behavior of wind vane under calm winds. From tests with several different percentiles of the fractional contribution from each source, a threshold criterion of the upper 25 percentiles was chosen to define the directionality of the sources. The sources are likely to be located in the directions that have high conditional probability values.

\section{Reconstructed mass (RCM) variables}

Elemental characterization of PM provides the basis for determining the fingerprints of possible sources of the PM. The combinations of some selected elements were used for estimating the composite variables, which represent the form in which the measured elements existed. Reconstructed mass variables include ammonium sulphate, soil, sea salt, black carbon, organic matter and smoke. RCM is therefore expected to be the addition of the variables.

Smoke is a product of combustion of fuels. It is an unwanted by-product of fire including those from stoves, candles, oil lamps and fireplaces (Begum et al., 2011). Potassium is an acceptable fingerprint element for smoke although it is also associated with sea salt and sedimentary rock. The relation for smoke is obtained by subtracting the contributions of sea salt and rocks from the total potassium (Weast and Astle, 1982). In this work, this equation was investigated for both fine and coarse fractions of the PM. Since both the BC and smoke are associated with fuel combustion, it is expected that the two should correlate well. However, we observed that no correlation existed between the composite variable smoke and the BC. There was also no significant correlation between the fine fraction $\mathrm{K}$ and $\mathrm{BC}$, suggesting that the equation may need further modification for this tropical location. The contribution of smoke to the fine PM was observed to be much less than $1 \%$, while the equation gave a negative contribution to the coarse PM. As a result, smoke was dropped from the RCM equation

Organic matter is calculated from organic carbon but because organic carbon was not analyzed in this work, organic matter is also left out of the equation. Black carbon was directly determined with the aid of a Dual-Wavelength Optical Transmissometer. The remaining parameters to be determined are therefore ammonium sulphate, sea salt and soil.

\section{Ammonium Sulphate}

Airborne sulphur is usually produced as $\mathrm{SO}_{2}$ gas, which readily converts to sulphate ions under normal atmospheric conditions. The sulphate ions can exist in the atmosphere as sulphuric acid $\left(\mathrm{H}_{2} \mathrm{SO}_{4}\right)$ producing acid rain or be partially neutralized to ammonium bisulphate $\left(\left(\mathrm{NH}_{4}\right) \mathrm{HSO}_{4}\right)$ or fully neutralized to ammonium sulphate $\left(\left(\mathrm{NH}_{4}\right)_{2} \mathrm{SO}_{4}\right)$ (Lee et al., 2001). If we assume that sulphur occurs in the atmosphere in one of these three forms, then clearly, the sulphur concentrations can be used to estimate the concentration of any of these sulphate species from the following relations (Malm et al., 1994):

$\left(\mathrm{NH}_{4}\right)_{2} \mathrm{SO}_{4}=4.125 * \mathrm{~S}$

for remote, urban sites at $100 \%$ neutralization,

$$
\left(\mathrm{NH}_{4}\right) \mathrm{HSO}_{4}=3.594 * \mathrm{~S}
$$

for urban, industrial sites at 50\% neutralization,

$$
\mathrm{H}_{2} \mathrm{SO}_{4}=3.063 * \mathrm{~S}
$$

for heavy industrial sites and Arctic region at $0 \%$ neutralization ( $\mathrm{no} \mathrm{NH}_{3}$ ).

In this work, a $100 \%$ neutralization condition is assumed so that the pseudo element ammonium sulphate is derived from Equation (2). The constants on the RHS of the equations are called the multiplicative molar correction factor (MCF). This was determined by accounting for the total molar weight $\left(\mathrm{W}_{\mathrm{m}}\right)$ of sulphate specie and then dividing it by the molar weight of sulphur. For example, the MCF in Eq. (2) was obtained thus:

$$
M C F=\frac{W_{m}\left[\left(\mathrm{NH}_{4}\right)_{2} \mathrm{SO}_{4}\right]}{W_{m}[s]}
$$




\section{Sea Salt}

Sea salt is mainly composed of sodium $(32 \%$ by weight) and chlorine (58\%) with minor components of $\mathrm{Mg}, \mathrm{S}, \mathrm{Ca}, \mathrm{K}$ and $\mathrm{Br}$ (Weast and Astle, 1982). The pseudo element representative of sea salt is expressed as a multiple of the measured sodium concentration:

Salt $=2.54^{*} \mathrm{Na}$

This equation assumes that the total sodium in the aerosol is associated with sea salt as sodium chloride, although sodium oxide of about $1 \%$ is present in the soil. Chlorine is not used as sea salt indicator due to its volatilization from the filters and because the additives in petrol are also a significant source of chlorine (White, 2008).

\section{Soil Composite}

For soil, the equation is based on the composition of sedimentary rocks (Pettijohn, 1963). Sedimentary rocks are made up of oxides such as $\mathrm{SiO}_{2}, \mathrm{Al}_{2} \mathrm{O}_{3}, \mathrm{CaO}, \mathrm{CO}_{2}, \mathrm{Fe}_{2} \mathrm{O}_{3}, \mathrm{H}_{2} \mathrm{O}, \mathrm{K}_{2} \mathrm{O}, \mathrm{MgO}$, $\mathrm{FeO}, \mathrm{C}, \mathrm{Na}_{2} \mathrm{O}, \mathrm{TiO}_{2}, \mathrm{SO}_{2}, \mathrm{P}_{2} \mathrm{O}_{5}$ and $\mathrm{Ba}$ in decreasing order of abundance. Since soil is formed from these rocks, it is assumed that the oxides are also present in the soil. Amongst these elements, $\mathrm{Si}, \mathrm{Al}, \mathrm{Ca}, \mathrm{Fe}, \mathrm{K}$ and $\mathrm{Ti}$ are chosen for the soil equation. The factors converting the elements to their respective oxides are determined by the ratios of the oxides to the elements:

$$
\begin{aligned}
& \frac{\mathrm{Al}_{2} \mathrm{O}_{\mathrm{s}}}{\mathrm{Al}}=1.89 ; \frac{\mathrm{SiO}_{2}}{\mathrm{Si}}=2.14 ; \frac{\mathrm{K}_{2} \mathrm{O}}{\mathrm{K}}=1.2 ; \\
& \frac{\mathrm{CaO}}{\mathrm{Ca}}=1.4 ; \frac{\mathrm{TiO}_{2}}{\mathrm{Ti}}=1.67 ; \frac{\mathrm{Fe}_{2} \mathrm{O}_{\mathrm{s}}}{\mathrm{Fe}}=1.43 ; \\
& \frac{\mathrm{FeO}}{\mathrm{Fe}}=1.29
\end{aligned}
$$

Since $\mathrm{Fe}$ is approximately equally split between $\mathrm{Fe}_{2} \mathrm{O}_{3}$ and $\mathrm{FeO}$ for most rocks, the multiplicative factor is just the average of the two, 1.36. Also, $\mathrm{K}$ may have other sources such as smoke. To minimize the error due to other sources, the ratio of $\mathrm{K} / \mathrm{Fe}=0.6$ for sedimentary rocks is used so that $\mathrm{K}$ is replaced by $0.6 \mathrm{Fe}$ in the equation. This leads to a modified factor for $\mathrm{Fe}$ as:

$$
\mathrm{MCF}_{\mathrm{Fe}}=1.36+0.6 * 1.2=2.08
$$

It has been established that these chosen oxides form about $86 \%$ of the sedimentary rock (Lide, 1992). Dividing the factors by 0.86 gives the final multiplicative factors for the soil equation:

$$
\begin{aligned}
& \text { Soil }=2.20 * A l+2.49 * S i+1.63 * \\
& C a+1.94 * T i+2.42 * F e
\end{aligned}
$$

The final RCM equation used therefore in this work is:

\section{$R C M=$ ammonium sulphate + sea salt + soil $+B C$}

\section{RESULTS AND DISCUSSION}

The distributions of scaled residuals of some selected species showed that, on the average, about $95 \%$ of the scaled residuals estimated by PMF were distributed between -3 and +3 for both the fine and coarse fractions. The reliability of the resolved factors was further established by the high correlation coefficients $\left(\mathrm{r}^{2}\right)$ between the PMF predicted PM and the measured PM for both fractions (Figures 2 and 3 ). For the fine fraction, $\mathrm{r}^{2}=0.84$ while it was 0.96 for the coarse fraction. The lower $r^{2}$ value for the fine fraction could be due to the unmeasured mass fraction which was higher for the fine fraction.

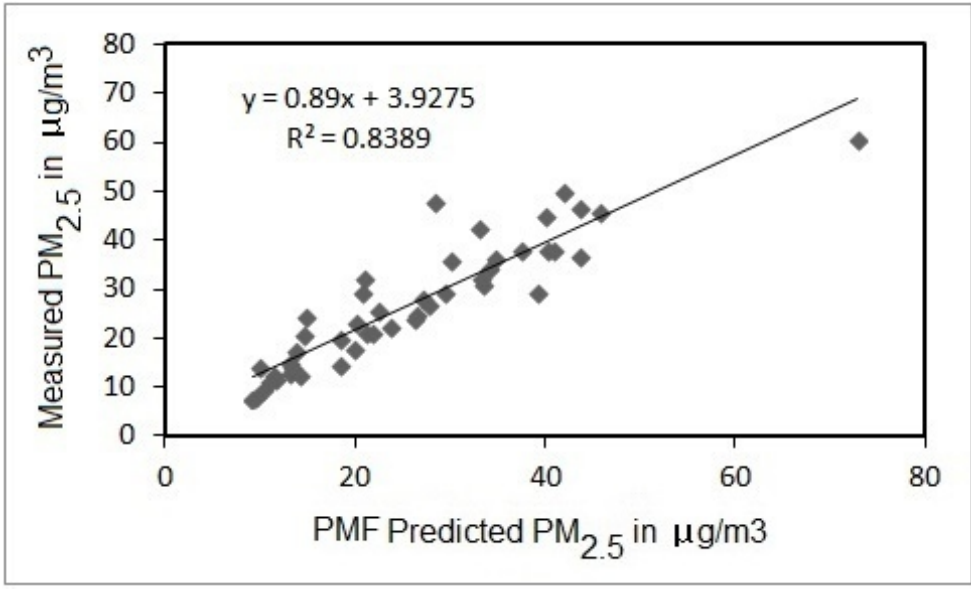

Figure 2: Correlation plot between the PMF predicted $\mathrm{PM}_{2.5}$ and the measured $\mathrm{PM}_{2.5}$ 


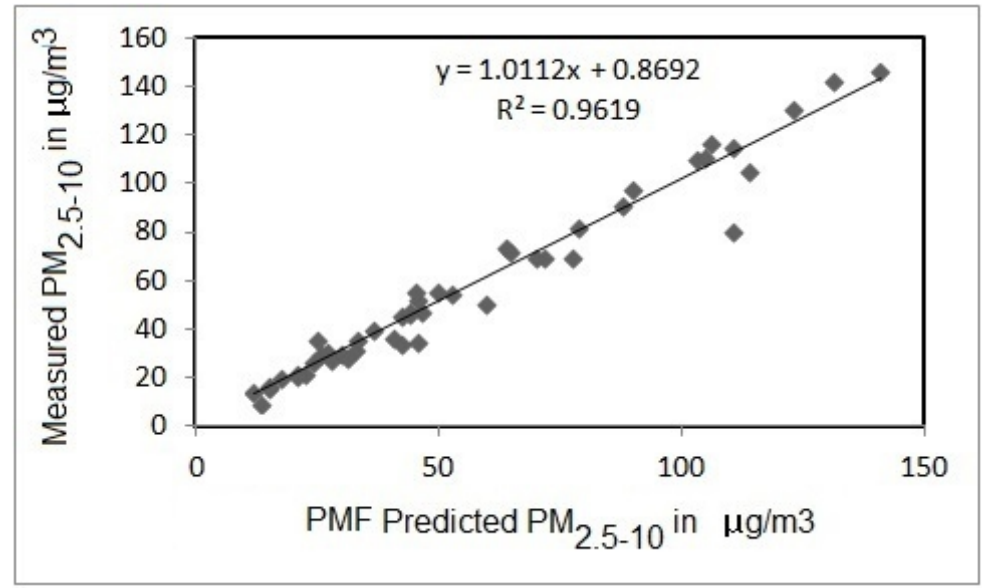

Figure 3: Correlation plot between the PMF predicted $\mathrm{PM}_{2.5-10}$ and the measured $\mathrm{PM}_{2.5-10}$
Source Profiles for $\mathrm{PM}_{2.5}$

Figures 4 and 5 show the five factors resolved by the PMF for the fine fraction. The factors are locally generated soil, vehicular emission, oil combustion, copper-rich source and refuse burning. The species contributing to the first factor are $\mathrm{Pb}(60 \%), \mathrm{V}(30 \%), \mathrm{Ni}(84 \%), \mathrm{Zn}(57$ $\%), \mathrm{BC}(40 \%), \mathrm{Cl}(32 \%)$, As (30\%) and $\mathrm{Br}(40 \%)$. Enclosed in the parentheses are the percentages of the species being contributed to the factor. The fingerprint elements for Vehicular emission according to Tiwari et al. (2013) are $\mathrm{Zn}, \mathrm{Ni}, \mathrm{Pb}, \mathrm{V}$, and BC. Begum et al. (2006) noted that vehicular emission factor can be identified by high loadings for BC. This factor was identified as vehicular emission. Zinc is characteristic of lubricating oil combustion; especially in the two stroke engine mixing oil with the fuel (Begum et al., 2006). It is an additive in lubricating oil, and in old vehicles, the piston consumes higher level of lubricating oil with the fuel thus emitting Zn (Begum et al., 2009). Zinc is also associated with mechanical abrasion of tires (Calvo et al., 2013; Almeida et al, 2013). Although there is a claim that leaded fuel is no longer in use, yet, $\mathrm{Pb}$ contributed about $60 \%$ of its concentration to this factor. This could be due to tear and wear from tires. On the average, vehicular emission contributed about $16 \%$ to the $\mathrm{PM}_{2.5}$ load. Figure 6 shows the pollution rose for all the resolved factors at different locations for the fine fraction. Generally, the results show that the local winds were predominantly south-westerly. This is consistent with the result of the back trajectory analysis (not presented in this work). The vehicular emissions sources were directed from the roads. 


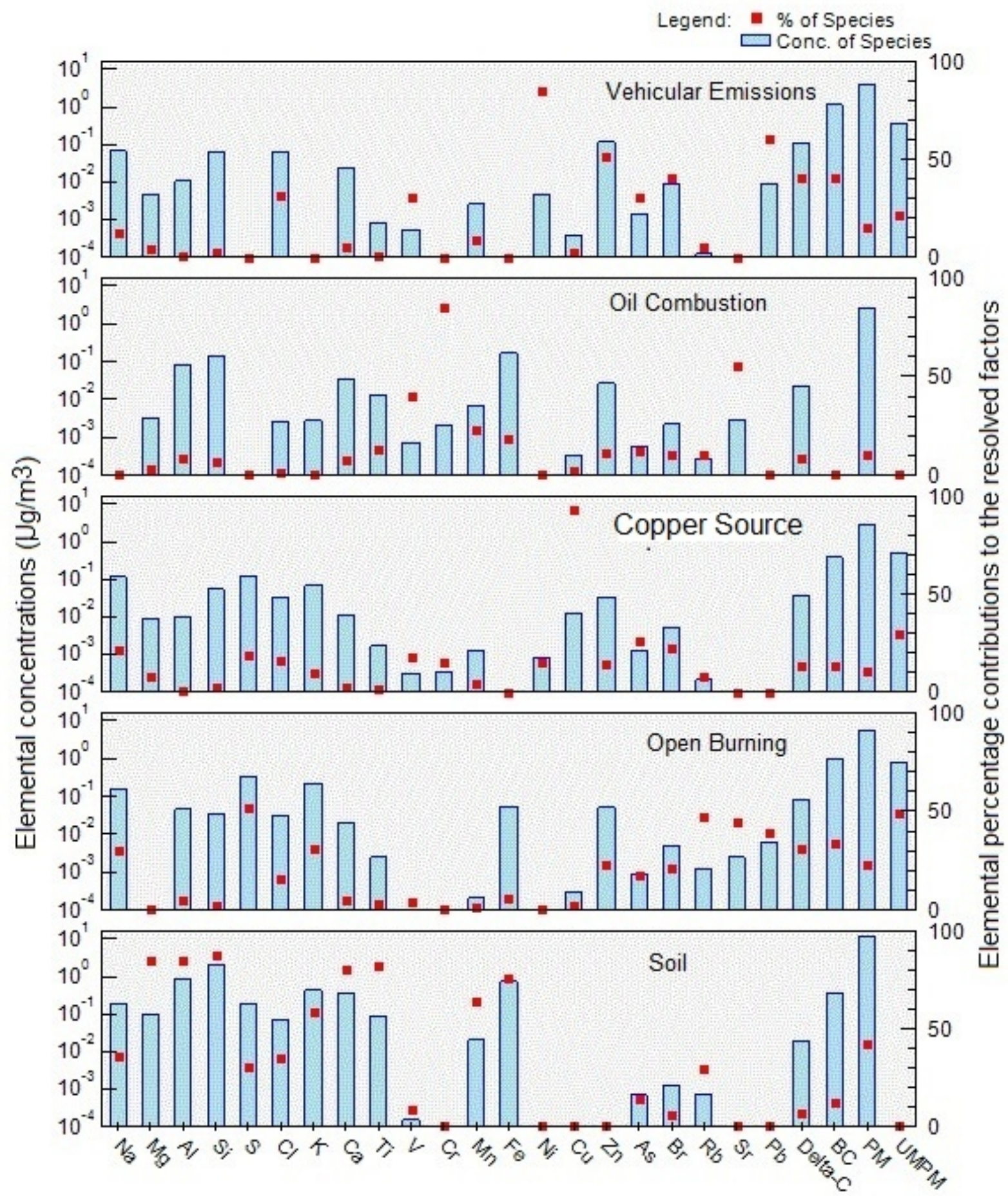

Figure 4: Source profiles resolved from $\mathrm{PM}_{2.5}$ samples. 


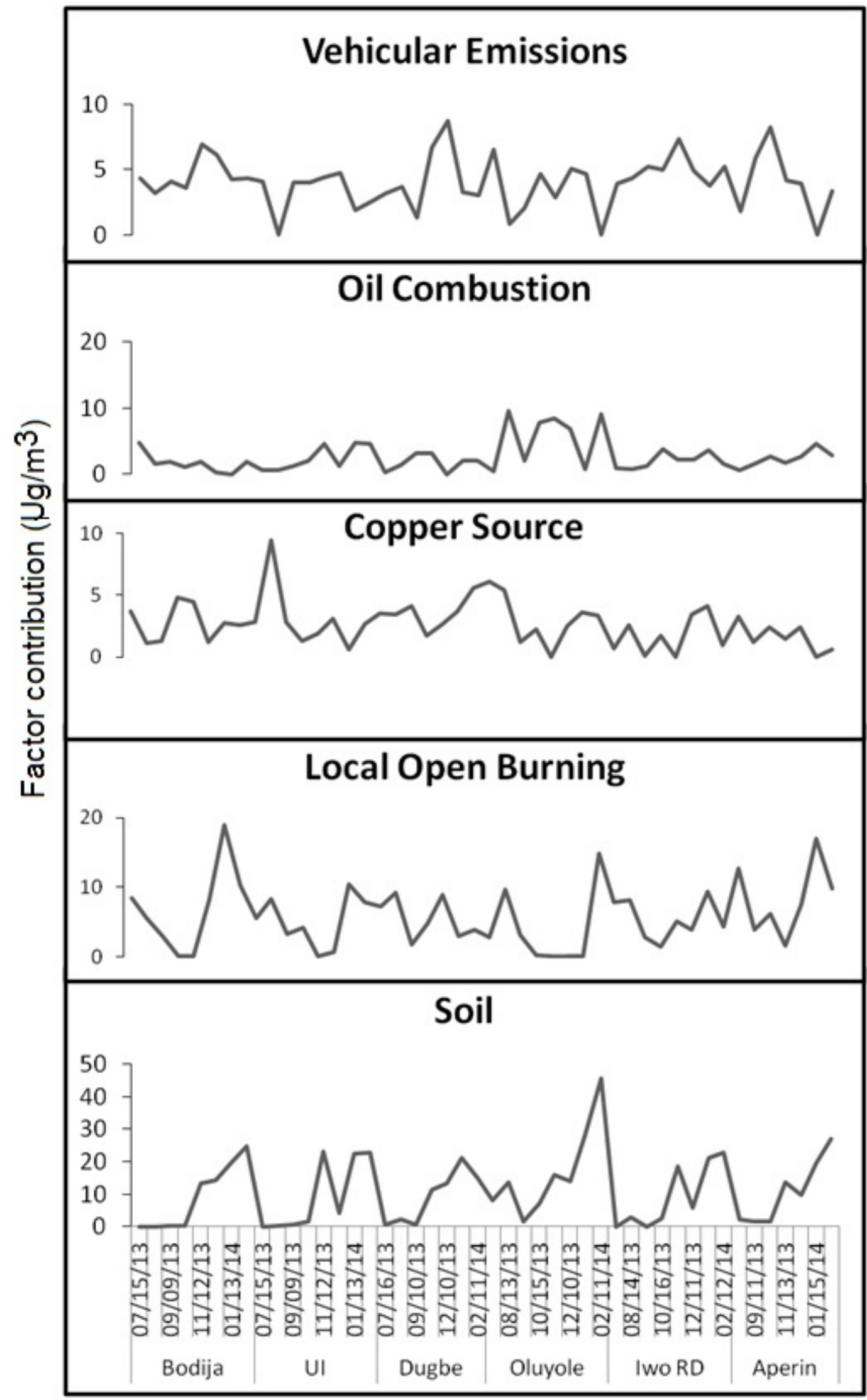

Figure 5: Spatial and temporal variation of PMF resolved source profile for the fine fraction 

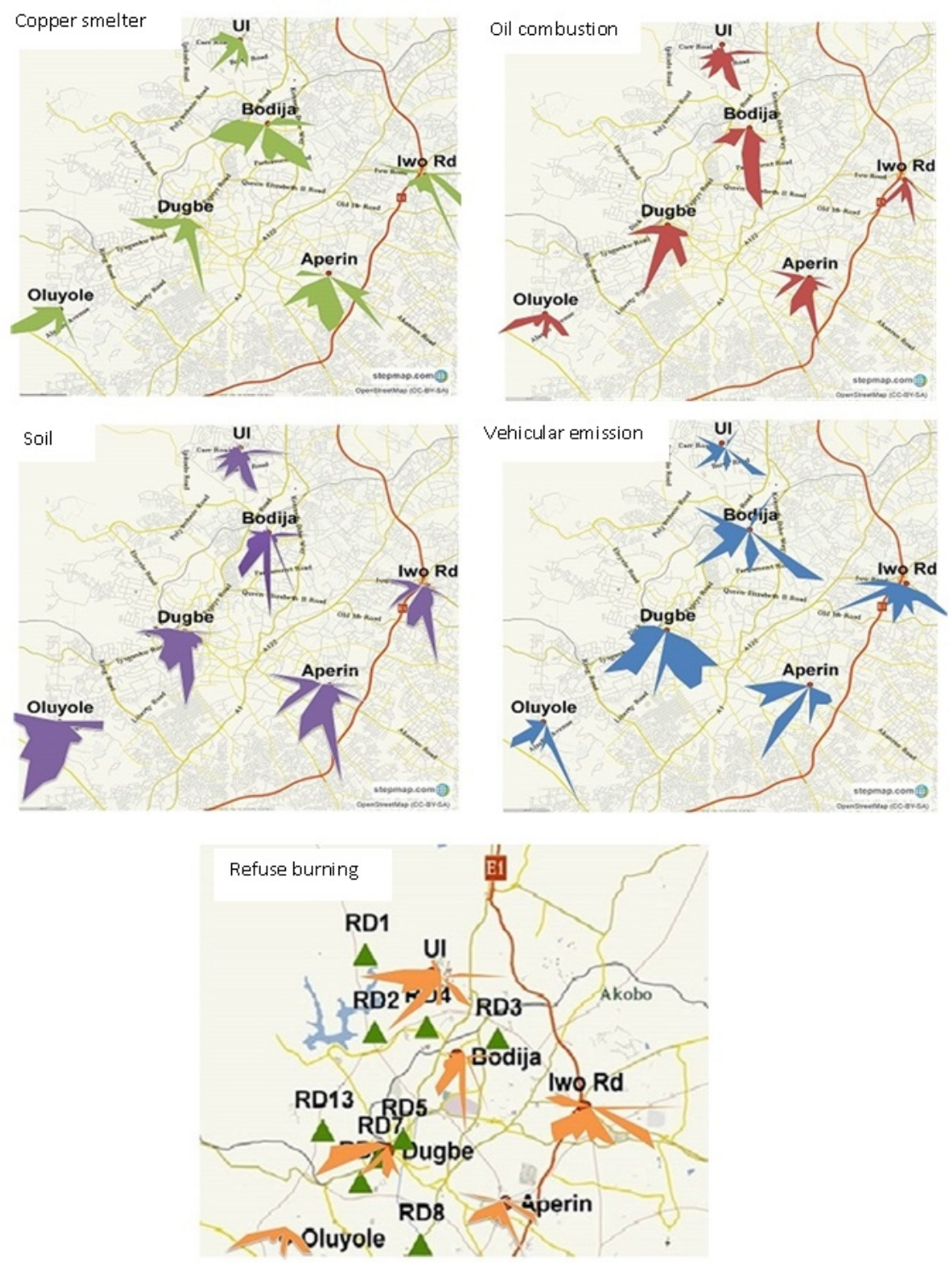

Figure 6: Pollution rose using conditional probability function for the fine fraction

The second factor is characterised by high loading in $\mathrm{V}(40 \%), \mathrm{Cr}(85 \%)$ and $\mathrm{Sr}(55 \%)$. Other contributors are $\mathrm{Mn}(22 \%), \mathrm{Fe}(18 \%)$ and $\mathrm{As}(12$ $\%)$. These elements have been identified as fingerprints for oil combustion (Calvo et al., 2013) which is characteristic of industrial emission (Coutant et al., 2003). This is depicted in Figure 5, where emission from oil combustion was more pronounced at Oluyole. Oluyole is an industrial estate, and the combustion of oil may probably be from power generation as a result of shortage of electricity supply from the national grid. This factor was observed to contribute only to the fine fraction. The contribution of oil combustion to the fine PMload was about $10 \%$.

The third factor is majorly made up of $\mathrm{Cu}(92 \%)$ with moderate contributions from As $(26 \%), \mathrm{Br}$ $(22 \%), \mathrm{Ni}(15 \%)$ and $\mathrm{Zn}(15 \%)$. It has been established that $\mathrm{Cu}$ and $\mathrm{Ni}$ are the primary emissions from welding processes (USEPA, 1994). Both the base and the filler metals used during welding processes contain $\mathrm{Cu}$. Zinc oxide fume is also produced during the welding of galvanized plate, while Nickel is present mainly in stainless steel. In Nigeria, the business of welding is so common that there is hardly a neighbourhood without welding activity. Although emission of $\mathrm{Cu}$ at UI site was the least, yet, Figure 5 shows that there was a spike at this site in August 2013. The probable reason could be due to the reconstruction of the zoological garden about $20 \mathrm{~m}$ away from the sampling site. The construction work involved the welding of 
ferrous metals. Welding involving these materials is strongly suspected to have led to the emission of the said metals which impacted the reception site. The contribution of this factor to fine fraction is $10 \%$.

The fourth factor has elemental specie contributions from S (52\%), K (31\%), Rb (47\%), $\mathrm{Zn}(23 \%), \mathrm{Pb}(39 \%)$ and $\mathrm{BC}(33 \%)$. Lead, $\mathrm{Zn}$ and $\mathrm{K}$ are strong fingerprints for refuse burning (Calvo et al., 2013). The high correlation observed between $\mathrm{Pb}$ and $\mathrm{Zn}$ indicated a common source which is refuse burning. The $\mathrm{Pb}$ might be from hazardous wastes such as used batteries and electronics, while the $\mathrm{Zn}$ could be from metallic wastes. Since municipal solid waste is an heterogeneous fuel, other implicated elements must have been from various dumped materials. This factor was only observed in the fine fraction and represented the second largest contributing factor to the fine PM which was $22 \%$. Figure 6 shows that emissions from refuse burning were obviously directed from the dumping sites (pyramids). About 20 dumping sites were located within Ibadan metropolis (Odunaike et al., 2008).

The major elemental species that contributed to the fifth factor are $\mathrm{Na}(35 \%), \mathrm{Mg}(84 \%), \mathrm{Al}(84$ $\%), \mathrm{Si}(87 \%)$, Ca $(79 \%)$, Ti $(81 \%), \mathrm{Fe}(76 \%), \mathrm{K}$ $(58 \%)$ and $\mathrm{Mn}(63 \%)$ for the fine fraction. High correlations existed between some of these elements, indicating a common origin in soil (Calvo et al., 2013). It has also been shown that these elements were not enriched in relation to soil (Akinlade et al., 2015). The average contribution of soil to $\mathrm{PM}_{2.5}$ was $42 \%$, representing the largest contributing factor. Many reasons can be attributed to this high contribution; the obvious ones being advected dust and road dust resuspension. Figure 5 shows that the effect of this was higher during the dry months for all the sites. This is partly due to the Harmattan dust haze and partly due to the dryness of land surfaces that enhanced dust re-suspension as a result of vehicular movement, especially when the roads are unpaved. The contribution of this factor was particularly high for Oluyole site because the roads were unpaved as at the time of sampling. The presence of some anthropogenic elements in this factor suggests that the source was local, and thus labeled as locally generated soil.

Source Profiles for $\mathrm{PM}_{2.5-10}$

Figures 7 and 8 show the five factors resolved by the PMF for the coarse fraction. The factors are continental soil, sea salt, copper-rich source, locally generated soil and vehicular emission. species contributing to the first factor in the coarse fraction were $\mathrm{Pb}(39 \%), \mathrm{Ni}(40 \%), \mathrm{Zn}(45 \%), \mathrm{BC}$ $(36 \%)$, As (19\%) and $\mathrm{Br}(46 \%)$. Aperin witnessed the highest volume of motor cycles and relatively old vehicles compared to other sites. This is probably why this source was most significant at Aperin for the coarse fraction. On the average, vehicular emission contributed about $7 \%$ to the coarse fraction. Figure 9 shows the pollution rose for all the resolved factors at different locations. Generally, the results show that the local winds were predominantly south-westerly. This is consistent with the result of the back trajectory analysis (Akinlade et al, 2015). 


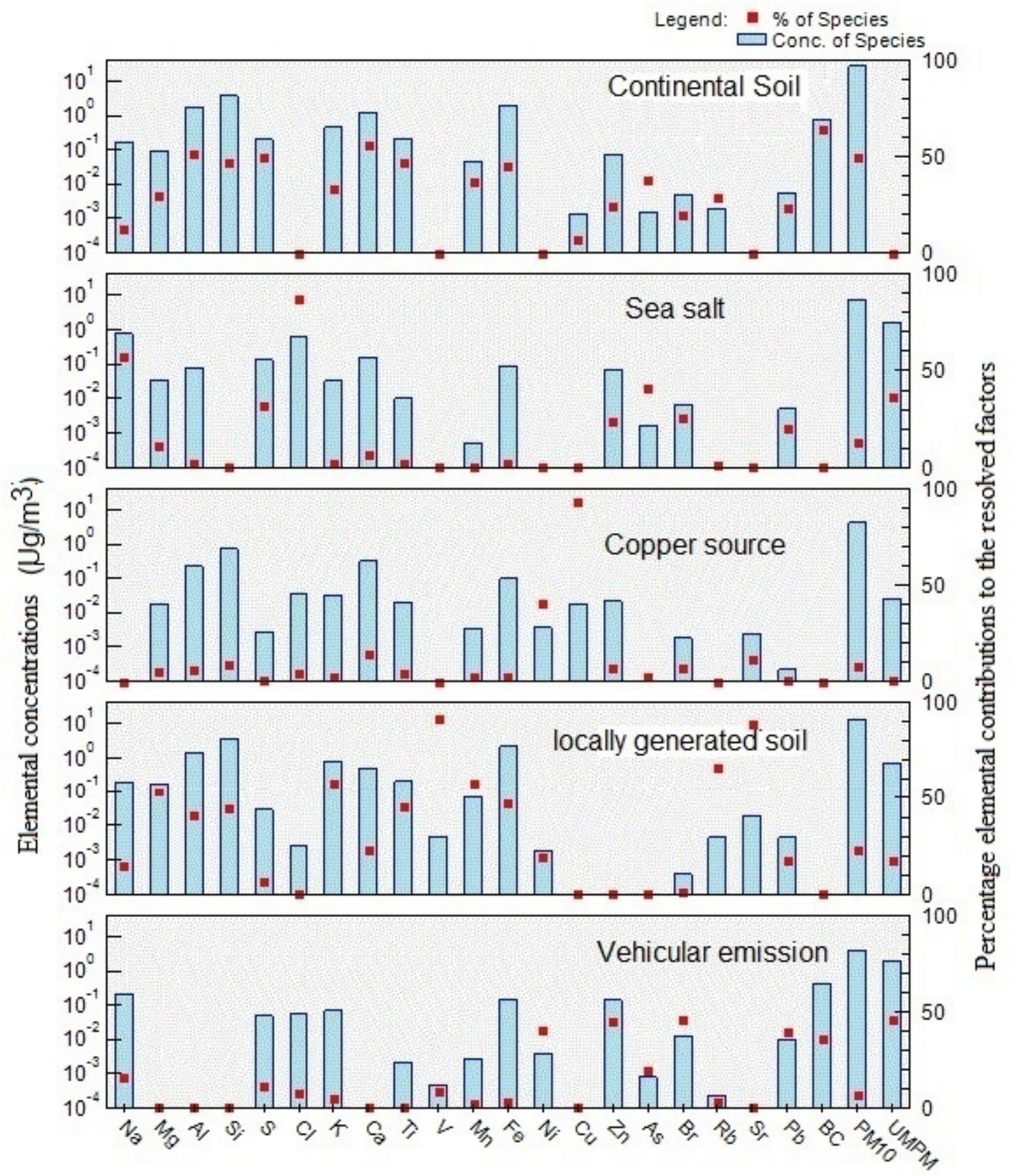

Figure 7: Source profiles resolved from $\mathrm{PM}_{2.5-10}$ samples 


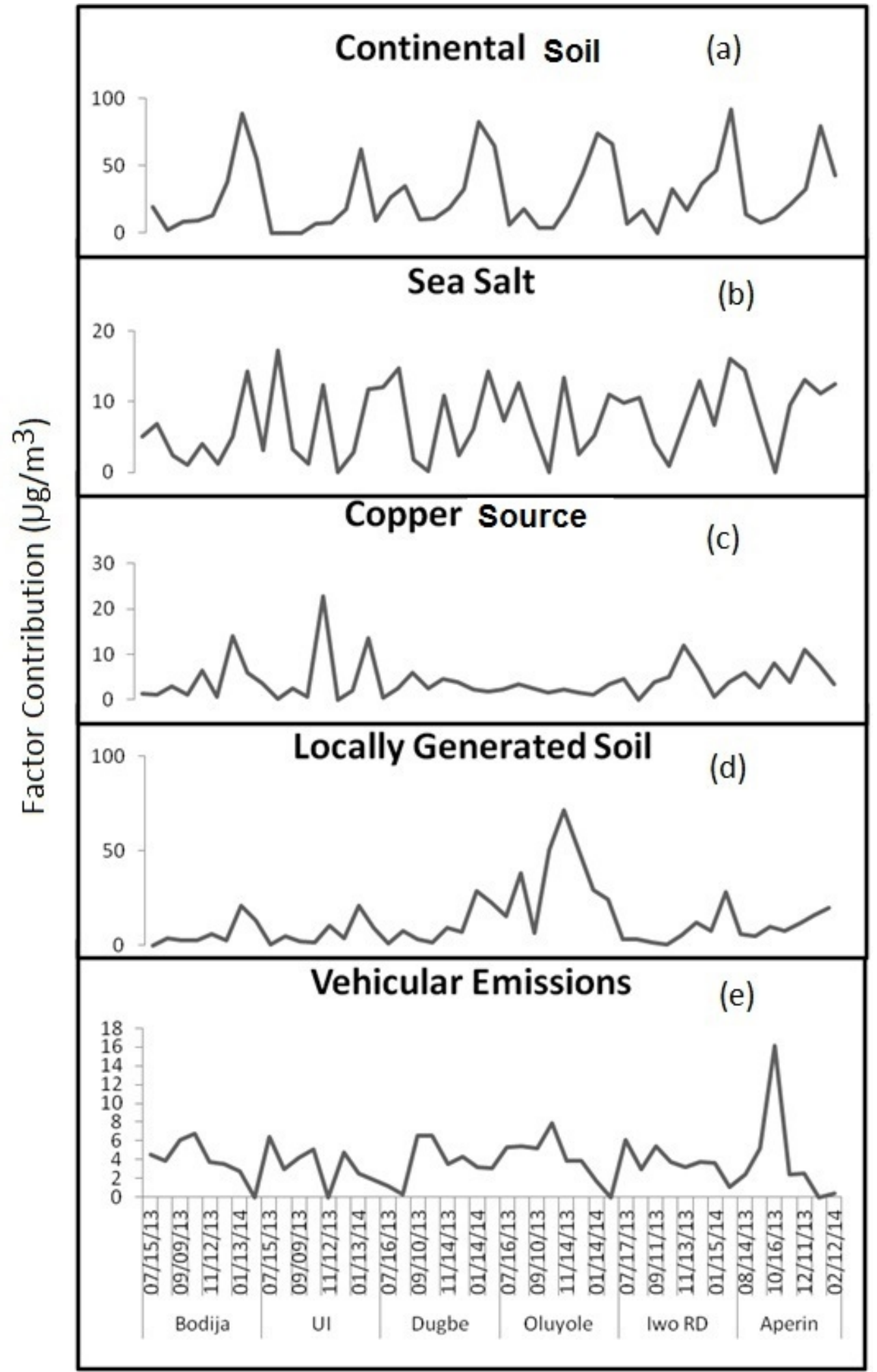

Figure 8: Spatial and temporal variation of PMF source profile for the coarse fraction. 

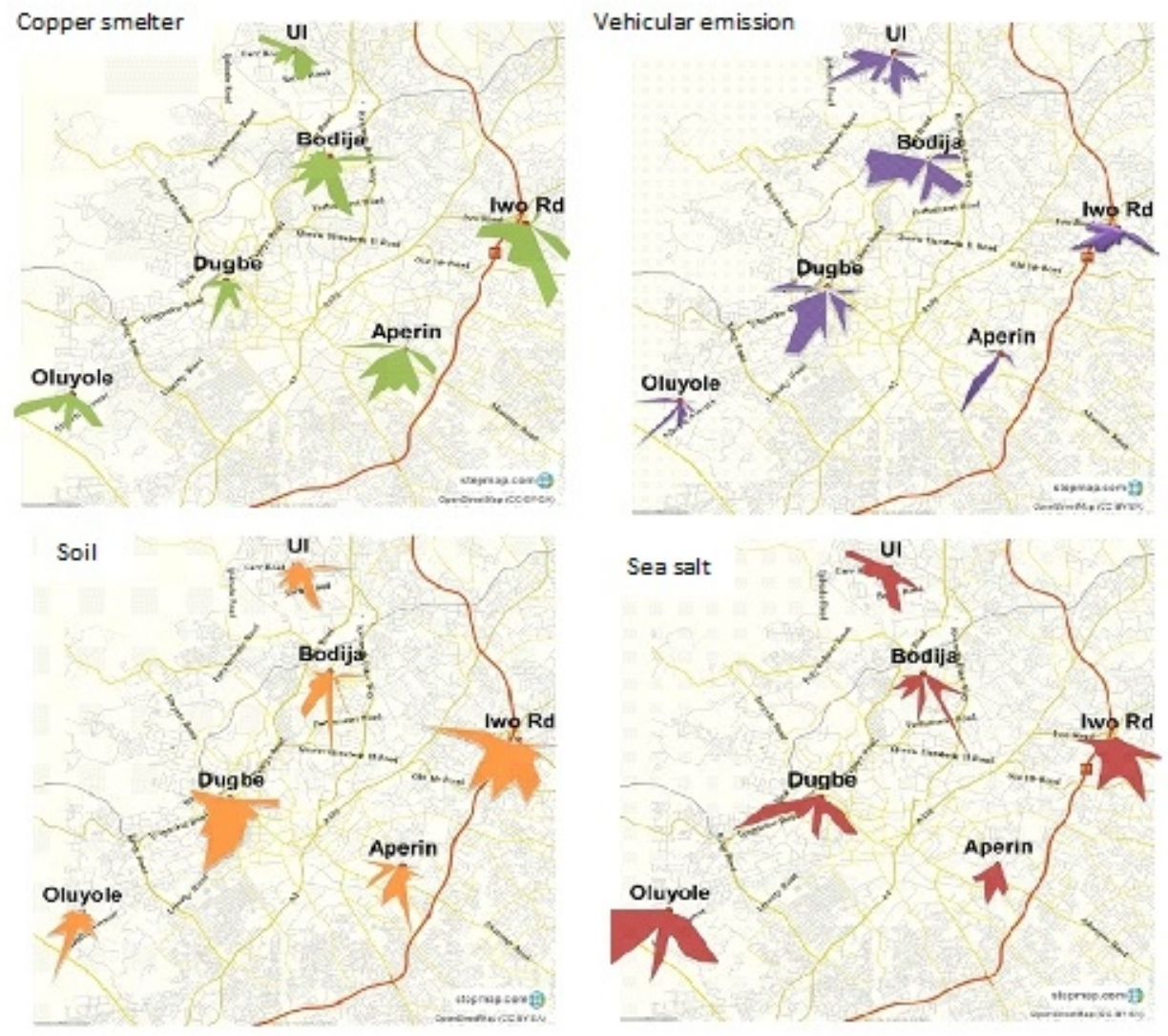

Figure 9: Pollution rose using conditional probability function for the coarse fraction

The major elemental species that contributed to the second factor were $\mathrm{Mg}(53 \%), \mathrm{Al}(40 \%), \mathrm{Si}(44$ $\%), \mathrm{K}(58 \%), \mathrm{Ti}(46 \%), \mathrm{V}(91 \%), \mathrm{Mn}(58 \%), \mathrm{Fe}$ $(47 \%)$ and $\mathrm{Rb}(66 \%)$. The behavior of this factor is in every way similar for both fractions. It is termed locally generated soil because of the presence of some anthropogenic elements. The third factor (copper-rich source) consists of $\mathrm{Cu}$ $(92 \%)$ and $\mathrm{Ni}(40 \%)$ as dominant species. This factor also exhibits similar behavior in both fine and coarse fractions. The contribution of this factor to coarse fractions is $8 \%$.

The fourth factor is made up of strong contributions from $\mathrm{Cl}(87 \%)$ and $\mathrm{Na}(57 \%)$. Other elements contributing to this factor include $\mathrm{S}(32 \%)$ and $\mathrm{Br}(25 \%)$. The factor is identified as sea salt. This factor contributed about $13 \%$ to the total coarse PM load of the study area and was only present in the coarse fraction. The direction of the emission from sea salt as revealed by the pollution rose (Figure 9) was predominantly south westerly. This is consistent with the result of HYSPLIT model analysis.
Finally, the fifth factor, continental dust, observed only in the coarse fraction has contributions from $\mathrm{Na}(35 \%), \mathrm{Mg}(30 \%), \mathrm{Al}(51 \%), \mathrm{Si}(46 \%), \mathrm{Ca}(55$ $\%), \operatorname{Ti}(47 \%), \mathrm{Fe}(45 \%), \mathrm{K}(33 \%), \mathrm{Mn}(37 \%)$ and BC $(60 \%)$. The even distribution of this factor across all the sites indicates that the origin was not localized and should probably be majorly due to the contribution of Harmattan dust which has its origin from the Sahara Desert and so it is evenly distributed across the sites. The average contribution of continental dust was $49 \%$.

Reconstructed Mass Variables and the Measured PM

Figures 10(a) and (b) show the relationship between the reconstructed mass and the particulate matter load for both the fine and coarse fractions during the period under investigation. The model provided a very good estimate of the particulate matter for both fractions. The estimated particulate matter showed a linear relationship with the measured fractions with $\mathrm{r}^{2}=$ 0.87 and 0.98 for the fine and coarse fractions, respectively. This implies that the reconstructed mass provides a better estimate of the coarse 
fraction of the suspended particulate matter in agreement with Begum et al. (2006). Figure 11 presents the relationship between the estimated composite variables and the measured PM for both fine and coarse fractions. While there was good correlation between the estimated soil and the PM for both fine and coarse fractions, the sulphate only has good correlation with the coarse PM. The correlation between the estimated salt and the measured PM can be considered poor for both fractions. The sampling locations are about $120 \mathrm{~km}$ from the Atlantic Ocean, supposedly to be the source of the sea salt component of the PM.

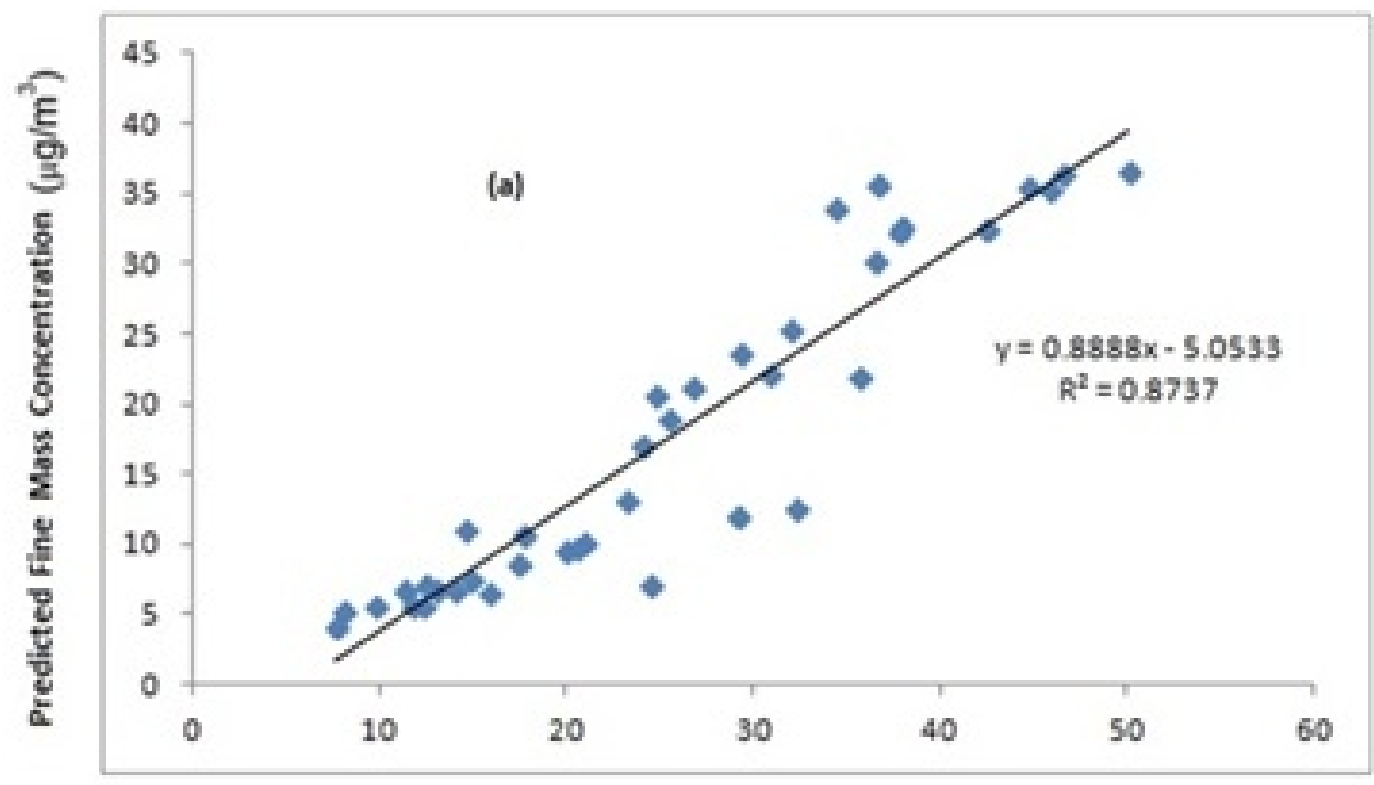

Measured Fine Mass Concentration $\left(\mu \mathrm{g} / \mathrm{m}^{3}\right)$

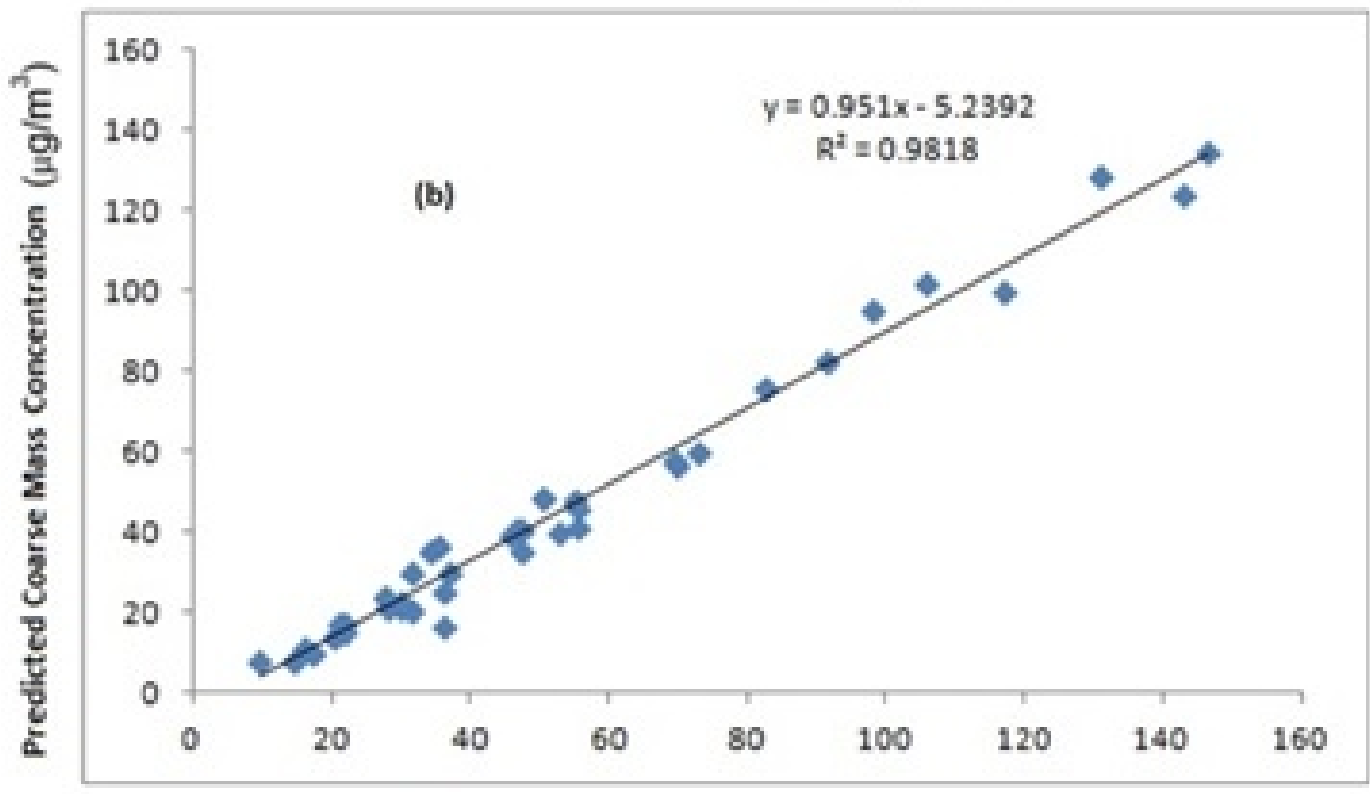

Measured Coarse Mass Concentration $\left(\mu \mathrm{g} / \mathrm{m}^{3}\right)$

Figure 10: Correlation Plots between the Reconstructed Mass (RCM) and the Measured Particulate Mass Load (a). for Fine Fraction and (b). for Coarse Fraction 


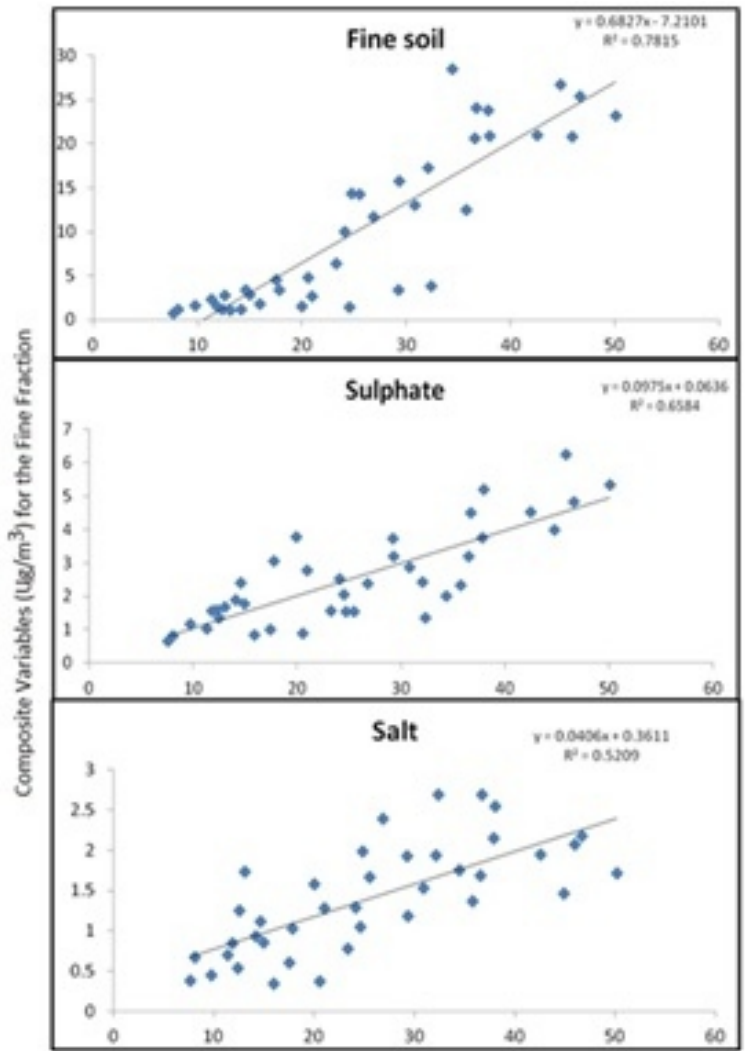

Measured Fine Mass Conoentrations $\left(\mu \mathrm{g} / \mathrm{m}^{3}\right)$

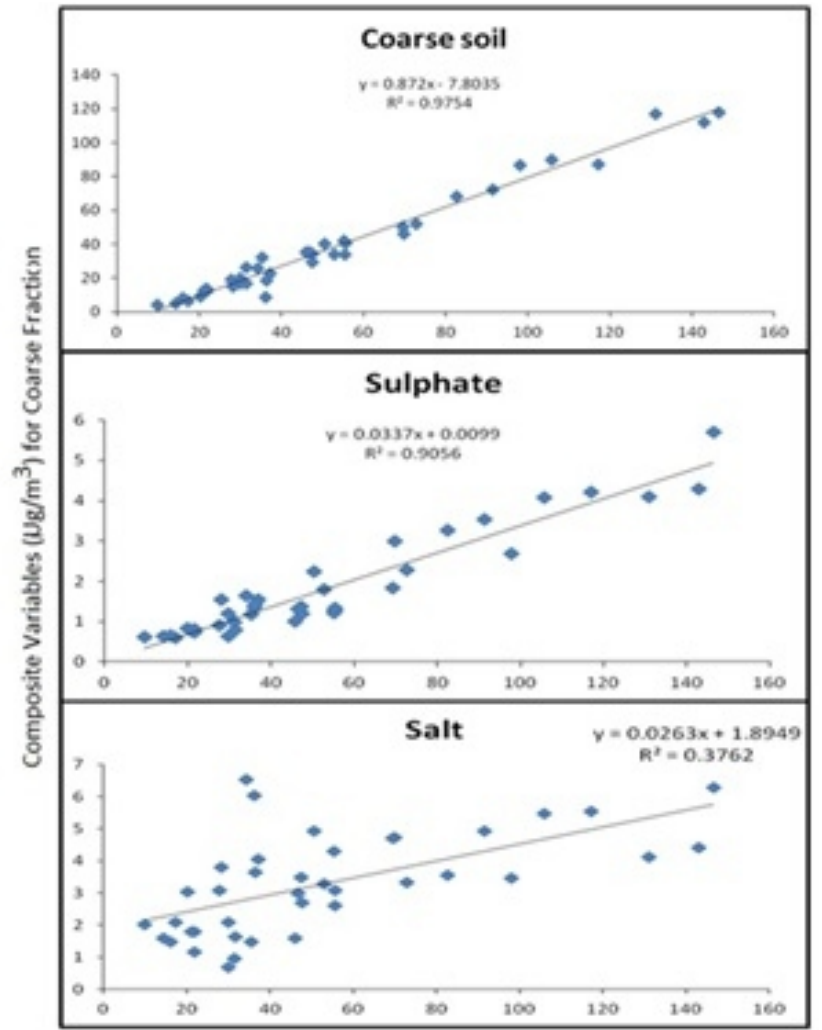

Measured coarse mass concentrations $\left(\mu \mathrm{g} / \mathrm{m}^{3}\right)$

Figure 11: Correlation Plots between the Composite Variables and the Measured Particulate Matter for the Fine and Coarse Fractions

Figures 12 (a) and (b) show the annual contribution of the composite variables to the total PM for the fine and coarse fractions, respectively. Suspended soil was responsible for about $73 \%$ of the coarse PM while it was only responsible for $43 \%$ of the fine PM. Black carbon and sulphate contributed 13 and $10 \%$, respectively to the fine PM and 3\% each to the coarse PM. The contribution of salt to the coarse

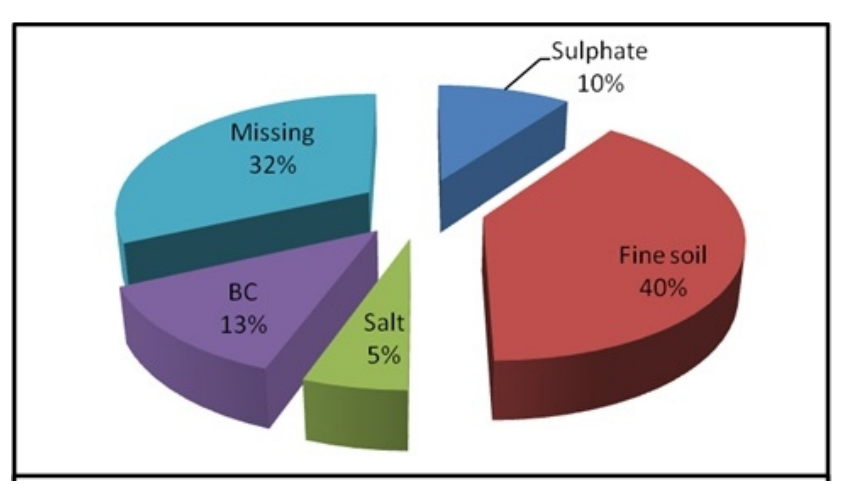

PM $(6 \%)$ was slightly higher than that of the fine fraction $(5 \%)$. In total, the RCM was able to account for about $85 \%$ of the coarse PM, putting the missing fraction at $15 \%$ while it accounted for just about $68 \%$ of the fine PM, putting the missing fraction at $32 \%$. This explains why the correlation between the RCM and the measured coarse PM was higher than that between the RCM and the measured fine PM.

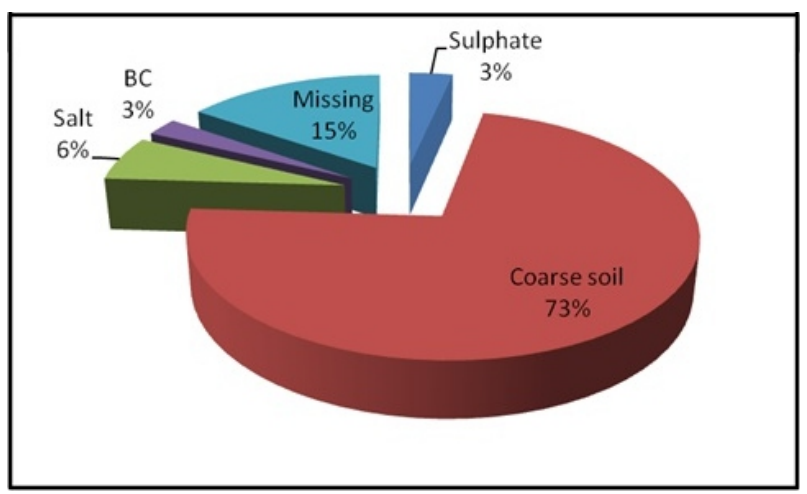

Figure 12: Compositional fraction of composite variables. (a). for fine fraction and (b). for coarse fraction 
Table 2: Comparison between PMF and RCM model results

\begin{tabular}{lll}
\hline Description & $\begin{array}{c}\text { RCM } \\
(\%)\end{array}$ & $\begin{array}{l}\text { PMF } \\
(\%)\end{array}$ \\
\hline Fine soil & 40 & 42 \\
Coarse soil & 73 & 72 \\
\hline
\end{tabular}

Composite variable soil was compared with the soil factor resolved by the PMF. The result is presented in Table 2 and the proportion attributed to soil by PMF agrees well with the calculated value using composite variable equation.

\section{CONCLUSION}

Positive Matrix Factorization receptor model was used for source apportionment of the pollutants measured over Ibadan, Nigeria. Five factors were resolved for both the fine and coarse fractions. For the fine fraction, soil dust, vehicular emission, open burning and copper source were the major sources of fine particulates over the city. Vehicular emission, continental soil, locally generated dust and copper source were the sources identified for the coarse particulates. Generally, the ambient air of Ibadan metropolis was majorly polluted by soil dust. Both locally generated soil dust and continental soil dust contributed $72 \%$ to the total PM load in the coarse fraction and $42 \%$ in the fine fraction. The contribution of emission from open burning was next significant (about $22 \%$ ) making the second largest contributor to the pollution level of Ibadan. The contributions from vehicular emission were 16 and $7 \%$ for fine and coarse fractions respectively. Conditional probability function was employed in determining the effect of local meteorology over the measured particulates. Emissions from traffic and open burning were directed from roads and dump sites respectively. This result showed a very good agreement with the result of the Hysplit model which depended on gridded satellite data (reported in earlier work; Akinlade, et al. 2015).Reconstructed mass model was also investigated for a tropical location in Nigeria. Good correlation existed between the reconstructed mass and the measured fine and coarse particulates with $r^{2}$ values of 0.87 and 0.98 respectively. The result of this work showed that re-suspended soil particulates were the major constituents of airborne particulate matter over Ibadan, with over $70 \%$ contribution to the coarse mass and over $40 \%$ contribution to the fine mass.

\section{AKNOWLEDGEMENT}

The authors acknowledge Obafemi Awolowo University, Ile-Ife, Nigeria for the Carnegie female staff fellowship award granted G.O. AKINLADE; Department of Chemical and Bimolecular Engineering and Centre for Air Resources Engineering and Science, Clarkson University, Potsdam, NY, USA for the support in the XRF and black carbon analyses. The research visit granted to G.O. AKINLADE by C2TN, Portugal is greatly appreciated.

\section{REFERENCES}

Akinlade, G.O., Olaniyi, H.B., Olise, F.S., Owoade, O.K., Almeida, S.M., Almeida-Silva, M. and Hopke, P.K. (2015). Spatial and temporal variations of the particulate size distribution and chemical composition over Ibadan, Nigeria. Environmental Monitoring and Assessment 187:544 DOI 10.1007/s10661-015-4755-4.

Almeida, S.M., Silva, A.V., Sarmento, S (2014) Effects of exposure to particles and ozone on hospital admissions for cardiorespiratory diseases in Setubal, Portugal. Journal of Toxicology and Environmental Health-Part A, 77 (14-16) 837-848.

Almeida, S.M., Almeida-Silva, M., Galinha, C., Ramos, C.A., Lage, J., Canha, N., Silva, A.V. and Bode, P. (2014). Assessment of the Portuguese k0-INAA laboratory performance by evaluating internal quality control data. Journal of Radioanalytical Nuclear Chemistry 300 (2) 581-587.

Almeida, S.M., Silva, A.I., Freitas, M.C., Dzung, H.M., Caseiro A., Pio; C.A. (2013) Impact of Maritime Air Mass Trajectories on the Western European Coast Urban Aerosol, Journal of Toxicology and Environmental Health, Part A, 76 (4-5) 252-262.

Ashbaugh, L., Malm, W. And Sadeh, W. (1985). A residence time probability analysis of sulphur concentrations at Grand Canyon national park. Atmospheric Environment, 19(8):1263-1270 
Bilkis, A. Begum, Swapan, K. Biswas, Philip, K. Hopke and David, D. Cohen (2006). Multi-element Analysis and Characterization of Atmospheric Particulate Pollution in Dhaka, Aerosol and Air Quality Research, 6 (4): 334-359.

Begum, B.A., Tazmin, A., Rabbani, K.A., Biswas, S.K. and Nasiruddin, M. (2009). Investigation of sources of particulate matter from the Tajgaon industrial area, Dhaka. Journal of Bangladesh Academy of Sciences, 33 (1): 71-85.

Bilkis A. Begum, Swapan K. Biswas, Gauri G.

Pandit, I. Vijaya Saradhi, Shahida

Waheed,

Naila Siddique, M.C. Shirani Seneviratne, David D. Cohen, Andreas Markwitz, Philip K. Hopke (2011). Long-range transport of soil dust and smoke pollution in the South Asian region, Atmospheric Pollution Research, 2: 151-157.

Calvo, A. I., Alves, C., Castro, A., Pont, V., Vicente, A. M. And Fraile, R. (2013). Research on aerosol sources and chemical composition: Past, current and emerging issues. Atmospheric Research, 120-121:128.

Cohen, D. (1999). Accelerator based ion beam techniques for trace element aerosol analysis. In Elemental analysis of airborne particulates.

Coutant, B. W., Engel-Cox, J. and Swinton, K.E. (2003). Second draft technical report (revision): Compilation of existing studies on source apportionment for PM2.5. Technical report, USEPA, Research triangle park, North Carolina 27711. http:/ / ready.arl.noaa.gov/HYSPLIT.php

Eluwa, S. E., Ajagbe, M.A., Tanko, E. U., Ojo, A. K. And Yusuf, G.O. (2012). Assessing intra-city road traffic in an indegeneous African city, Ibadan, Nigeria. IRACSTEngineering Science and Technology: An international Journal of (ESTIJ, 2(2):221228).

Hopke, P., Xie, Y., Raunemaa, T., Biegalski, S., Landsberger, S., Maenhaut, W., Artaxo, P., \& Cohen, D. (1997). Characterization of the gent stacked filter unit $\mathrm{PM}_{10}$ sampler. Journal of Aerosol Science and
Technology, 27:726-735.

Kayode, A. and Omole, F. (2011). Some socioeconomic factors affecting solid wastes generation and disposal in Ibadan metropolis, Nigeria. Journal of Environmental Issues and Agriculture in Developing Countries, 3(1):55-64.

Lee, E., Chan, C. K. and Paatero, P. (1999). Application of positive matrix factorization in source apportionment of particulate pollutants in Hong Konk. Atmospheric Environment, 33:32013212.

Lide, D.R. (1992). CRC Handbook of Chemistry and Physics. CRC Press, Boca Raton, Fla. pp. 14-17.

Malm, W.C., Sisler, J.F., Huffman, D., Eldred, R.A. and Cahill, T.A (1994). Spatial and seasonal trends in particle concentration and optical extinction in the United States. Geophysical ResearchA-Atmospheres, 99:1347A-1370.

Odunaike, R., Laoye, J., Alausa, S., Ijeoma, G. and Adelaja, A. (2008). Radiation emission characterization of waste dumpsites in the city of Ibadan in Oyo State of Nigeria. Research Journal of Environmental Toxocology, 2(2):100-103.

Paatero, P. and Tapper, U. (1994). Positive matrix factorization: A non-negative factor model with optimal utilization of error estimates data values. Environmetrics, 5:111-126.

Pettijohn, F. J. (1963). Chemical composition of sandstones-excluding carbonate and volcanic sands, in Fleischer, M., ed., Data of Geochemistry, sixth edition, U. S. Geological Survey Professional Paper 440-S, 21 pages.

Pope, C., Burnett, R., Thun, M., Calle, E., Krewski, D., Ito, K., and Thurston, G. (2002). Lung cancer, cardiopulmonary mortality, and long-term exposure to fine particulate air pollution. Journal of American Medical Association, 287(9):1132-1141.

Rees, S.L., Robinson, A.L., Khlystov, A., Stanier, C.O. and Pandis, S.N. (2004). Mass balance closure and the federal reference method for PM2.5 IN Pittsburgh, Pennsylvania. Atmospheric Environment, 38:3305- 
3318.

Tiwari, S., Pervez, S., Cinzia, P., Bisht, D. S., Srivastava, A.K., and Chate, D. (2013). Chemical characterization of atmospheric particulate matter in Delhi, India, part II: Source apportionment studies using PMF 3.0. Sustaining Environment Research, 23(5):295-306.

USEPA (1994). Development of particulate and hazardous emission factors for electric arc welding (ap-42, section 12.19) revised final report. Technical report, United States Environmental Protection Agency.

Weast, R.C. and Astle, M. (1982). CRC Handbook of Chemistry and Physics, 63rd Edition. CRC Press Inc., Boca Raton, Florida.

White, W. (2008). Chemical markers for sea salt in improve aerosol data. Atmospheric Environment, 42:261-274. 